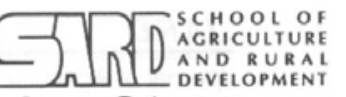

কৃষि ও পল्षी উन्नয়न অनूষদ
Available online at

http://www.banglajol.info/index.php/jard
J ARD

Journal of Agriculture

\& Rural Development

\title{
Rice-Fish Culture and its Potential in Rural Development: A Lesson from Apatani Farmers, Arunachal Pradesh, India
}

\author{
S. K. SAIKIA ${ }^{*} \&$ D. N. DAS \\ Department of Zoology, Rajiv Gandhi University, Rono Hills, Itanagar, Arunachal Pradesh, India
}

\begin{abstract}
Rice-based fish farming, though, inevitable as a mean of double crop production from the unit land, is often proves as cost-effective practice for marginal and poor farmers. The lack of adequate knowledge and support to farmers keep them away from the benefits of rice-based fish farming. The novel technique adopted by Apatani farmers in Lower Subansiri district of Arunachal Pradesh, India reduces the knowledge gap to achieve optimum benefit from such farming practice. The farmers enjoy a fish production of $500 \mathrm{~kg}$ per hactor per year without providing any supplementary feed to the fish stocked in their rice-fields. The economic return of the farmers was estimated up to $65.8 \%$ per annum from their rice-fish integrated fields. The system of rice-based fish farming by Apatani farmers has, therefore, bears immense potentiality to be recognized as low cost and sustainable farming practice and could be a significant breakthrough for poor and marginal farmers of the rest of the World.
\end{abstract}

Key words: Rice-fish culture, Apatani farmers, poverty alleviation, low-cost technology, Common carp.

\section{INTRODUCTION}

Rice-based fish farming is the main source of earning in many parts of the world. There is an estimated 81 million ha of irrigated rice lands worldwide, with an additional 11 million ha of flood prone land under rice cultivation (Halwart, 1998). Presently, the system of rice fish is being practiced in Bangladesh, Cambodia, China (1.2 million ha), Egypt (173000 ha), Indonesia (138,000 ha), Republic of Korea, Madagascar (13,000 ha), Thailand (3 million ha) and Vietnam (40,000 ha) (Halwart, 1998). The practice supports a large share of the rural population in South, Southeast and East Asia and in parts of West Africa. In these places, rain-fed rice fields are designed to store water for extended periods, creating aquatic ecosystems with many similarities to natural floodplains (Heckman, 1979). These floodplain habitats of rice are later stocked by fish and grown throughout the wet season. Fishing from these rice-based farming systems is often carried out on regular, occasional or part-time basis, making a significant contribution to livelihoods of poor farmers.

However, the input cost in terms of feed, labor and infrastructure for rice-based fish farming is often a barrier for poor and marginal farmers. There exists many possible suggestive approaches to overcome one or more such type of barriers, but all these are still in conceptual form. However, Apatani farmers from Lower Subansiri district in Arunachal Pradesh, India have practiced a very unique traditional rice-based fish farming practice in their waterlogged rice-fields which not only

* Corresponding author: Deptt. of Zoology, RGU, Rono Hills, Itanagar, Arunachal Pradesh, India, E-mail: sksaikai@yahoo.com

(C) 2008 School of Agriculture and Rural Development, Bangladesh Open University, All rights reserved. 
gives good economic return to support their families' demands but also exposes a very low-cost fish farming technology for rest of the world.

\section{Location of apatani plateau}

The Apatani Plateau is located in a hilly plateau in Lower Subansiri district of Arunachal Pradesh, India (Fig. 1). The 'tribe' inhabited is known as 'Apatani', hence name of the plateau is 'Apatani Plateau'. The Apatani Plateau is geographically placed at 5000 feet above mean sea level and $26^{\circ} 50^{\prime}-98^{\circ} 21^{\prime} \mathrm{N}$ latitude and $92^{\circ} 40^{\prime}$ and $94^{\circ} 21^{\prime} \mathrm{E}$ longitude. Apatani tribe is the only agrarian tribe practicing settled agriculture in this part of the state. The men and women both take part in agricultural works. Rice is the principal crop in addition to millet and other grain crops in their homestead plots. The cropping pattern of the area includes monocropping of wet rice once in a year in their wet plots associated with year round sequential production of various vegetables on field dykes and in their homestead plots.

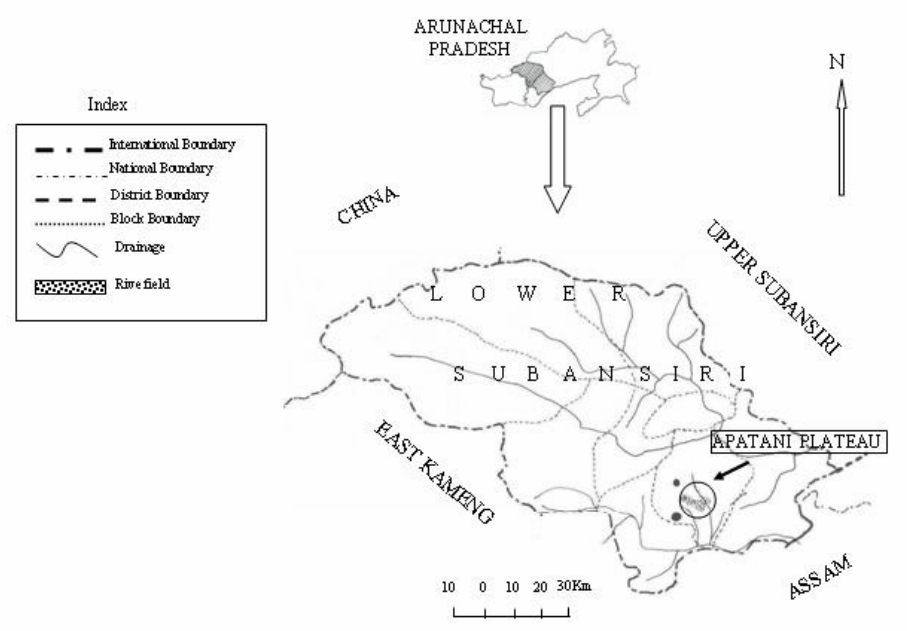

Fig. 1. Location map of Apatani Plateau (Arunachal Pradesh, India)

Out of the total 21,781 ha irrigated rice areas in the State, the plateau covers an area of 10135 $\mathrm{km}^{2}$. Average rainfall is $108.1 \mathrm{~cm}$ and temperature covers a range from maximum $30.6^{\circ} \mathrm{C}$ to minimum $1.1^{\circ} \mathrm{C}$. The relative humidity varies from $36.5 \%$ to $82.8 \%$.

\section{Rice-fish culture in arunachal pradesh}

The total water area of Apatani Plateau is 715.7 ha and rice-fish culture covers approximately 592.0 ha (Das, 2002) (Fig. 2). The climate of the state is conducive for rice-fish integration. Temperature with a range from $14-35^{\circ} \mathrm{C}$ shows wide fluctuations favoring both warm and cold-water fisheries. The technique of rice-fish farming among the Apatani farmer is a simultaneous culture and practiced in wet rice terraces of Apatani Plateau. All the strains of Common carp (Cyprinus carpio) are grown along with local rice cultivars, viz. Amo, Mypia and Pyapee. The strains of the fish speceies include Cyprinus carpio specularis (Mirror carp), C .carpio communis (Scale carp) and C. carpio nudus (Leather carp).The preparation of the rice fields for fish culture begins in April-May. The fry stages (15$20 \mathrm{~mm}$ ) of fish are stocked in the field after ten days of transplanting of rice seedlings. Farmers used to feed their rice fields with stream water by connecting them directly to community irrigation channel. Water level in the field is maintained at $20-30 \mathrm{~cm}$ during culture period whereas the depth of the canal is maintained at $40-45 \mathrm{~cm}$. They do not use any feed supplement for the fish during culture period. Generally, fishes grow up to $400-500 \mathrm{~g}$ within 3-4 months (Fig. 3). The production rate is $500 \mathrm{~kg} \mathrm{ha}^{-1}$ season $^{-1}$. Farmers used to receive a profit of Rs. 80/kg (\$2 only) over the initial cost of Rs. 1000 (\$ 
$25) / 1000$ fingerling at the time of stocking. Thus the profit provides more than $50 \%$ earning to the farmers in addition to their normal rice crop.

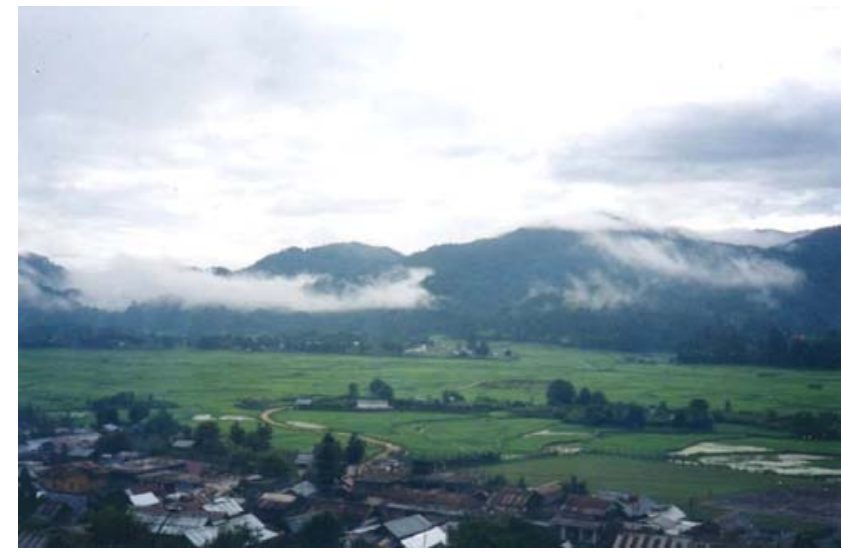

Fig. 2. A look to the rice-fish integrated fields of Apatani Plateau (Arunachal Pradesh, India)

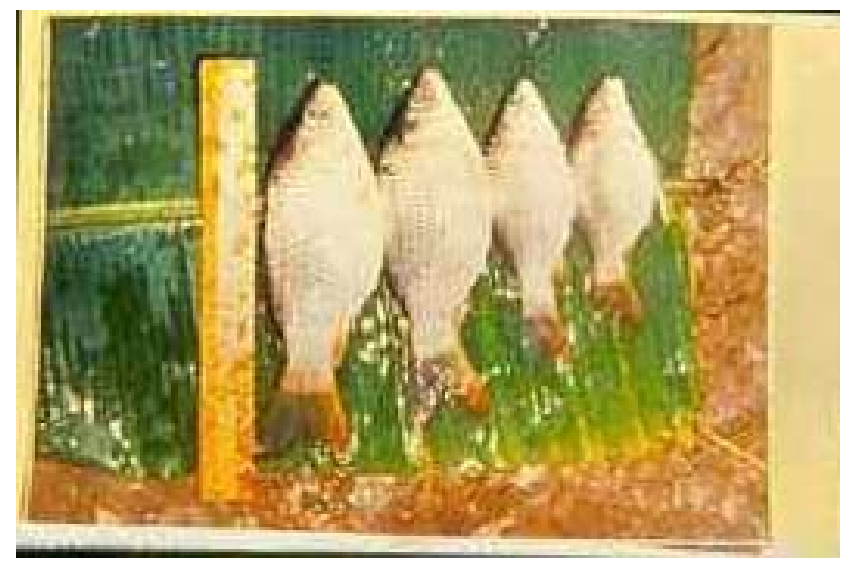

Fig. 3. Common carp (Cyprinus carpio L.) harvested from rice-fish integrated fields of Apatani Plateau (Arunachal Pradesh, India)

\section{The existing technique and economy}

Refuge trenches are prepared in the rice-fields for facilitating movement and providing shelter to fish during warmer hours of the day. The depths of these trenches are of 25-35 cm and constructed either perpendicularly to each other or sometimes irregularly (Fig. 4). Two outlets are fitted to these trenches of where the top one is used to release excess water and the bottom one is used for drying up of the field water for harvesting the fish. In terraces the dyke at higher elevation is constructed with a height of $0.9 \mathrm{~m}$ to $1.5 \mathrm{~m}$ and in the dyke at lower elevation with $40-60 \mathrm{~cm}$ heights. It facilitates complete drying of water from elevated rice-plots. The water outlets are strictly guarded to prevent fish escape with bamboo screens made up of bamboo slits during management operation. The healthy seedlings maximum 2-3 in numbers are planted at a distance of $20-25 \mathrm{~cm}$ from hill to hill and 10 days after plantation fish fries $(15-20 \mathrm{~mm})$ are stocked at the rate of $2500 \mathrm{ha}^{-1}$. Sometimes cow dung is used as organic manure at the time of field preparation. No chemical fertilizer is used in rice filed plots but Azolla and Lemna are allowed to grow there as nitrogen fixer. Sequential weeding operation is performed mechanically round the rice-growing season. Fishes are harvested after 3-4 months of rearing in the field. 


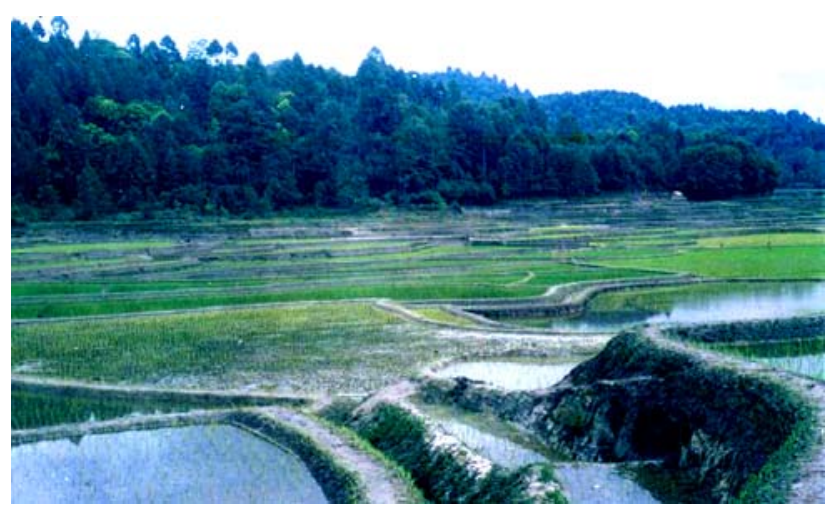

Fig. 4. Irrigation channels in the rice-fish integrated fields of Apatani Plateau. These irrigation channels feed rice-fields of Apatani Plateau with water collected from streams of surrounded hilly plots.

Though the technique of culture is low input and traditional but fetches more output compared to annual investment. It is also evident that $30 \%$ higher economic return is obtained from rice-fish culture in comparison to rice cultivation. A comprehensive economic analysis of the existing system has been presented in Table 1 . There exist huge potentiality to increase the yield for both rice and fish through adoption of modern organic farming techniques.

Table 1. Economics of terrace rice-fish culture system (one hectare, expenditure corresponds to Indian value; \$1 = Rs. 43.00 appr. on June, 2008)

A. Fixed cost

\begin{tabular}{lccc}
\hline \multicolumn{1}{c}{ Subject } & Total cost (Rs.) & Economic life (Year) & Depreciation cost (Rs.) \\
\hline 1. Terracing & 35,000 & 10 & 3,500 \\
2. Trenches & 2,000 & 2 & 1,000 \\
3. Ploughing and other Installation & 5,000 & 5 & 1,000 \\
(Bamboo guard, trenches, net etc.) & & & 1,600 \\
4. Bullock (2) & 8,000 & 5 & - \\
5. Land & 12,000 & - & 7,100 \\
\hline Total & 62,000 & & \\
\hline
\end{tabular}

B. Recurring cost

(a) Factor services

\begin{tabular}{lc}
\hline Subject & Amount (Rs.) \\
\hline 1. Labor charges for seed bed preparation, Transplantation, Deweeding, reaping etc. & 4,000 \\
2. Labor charges for fish culture operations (2 Labor ha ${ }^{-1}$ day $^{-1}$ at the rate of Rs.120.00 & 5,000 \\
labor $^{-1}$ day $\left.^{-1}\right)$ & 1,000 \\
3. Marketing cost & 10,000 \\
\hline Total & \\
\hline
\end{tabular}

(b) Materials required

\begin{tabular}{lc}
\hline Subject & Amount (Rs.) \\
\hline 1. & Fish Seed (all species for 5,000 $\mathrm{kg} \mathrm{ha}^{-1}$ at the rate of Rs. 300/1,000 ${ }^{-1}$ seed) \\
2. Rice seed & 750 \\
\hline Total & 1,000 \\
\hline
\end{tabular}

(c) Miscellaneous expenses (Rs.)

Total Recurring expenses $(a+b+c)(R s$. 
C. Annual Investment

\begin{tabular}{lc}
\hline Subject & Amount (Rs.) \\
\hline (a) Annual depreciation cost on fixed capital & 2,600 \\
(b) Interest at the rate of 12\% on fixed capital & 7,440 \\
(c) Annual recurring cost & 13,250 \\
(d) Interest at the rate of 15\% on recurring cost & 1,987 \\
\hline Total & 25,277 \\
\hline
\end{tabular}

D. Annual turnover

\begin{tabular}{|c|c|c|c|c|c|c|}
\hline Subject & & & & & & ount (Rs.) \\
\hline (a) Sale of fis & $\mathrm{h}$ at an average $\mathrm{r}$ & ate of Rs $100 / \mathrm{k}$ & for $500 \mathrm{~kg}$ & & & 50,000 \\
\hline (b) Sale of $p$ & iddy @Rs. 6 for 4 & $000 \mathrm{~kg}$ & & & & 24,000 \\
\hline Total & & & & & & 74,000 \\
\hline E. Summary & & & & & & \\
\hline $\begin{array}{c}\text { Fixed } \\
\text { Capital (Rs.) }\end{array}$ & $\begin{array}{c}\text { Annual } \\
\text { investment (Rs.) }\end{array}$ & $\begin{array}{c}\text { Annual } \\
\text { turnover (Rs.) }\end{array}$ & $\begin{array}{c}\text { Annual } \\
\text { profit (Rs.) }\end{array}$ & $\begin{array}{l}\text { Return to fixed } \\
\text { capital (\%) }\end{array}$ & $\begin{array}{c}\text { Return to } \\
\text { investment (\%) }\end{array}$ & $\begin{array}{c}\text { Profit to } \\
\text { turnover (\%) }\end{array}$ \\
\hline 62,000 & 25,277 & 74,000 & 48,723 & 78.58 & 192.75 & 65.84 \\
\hline
\end{tabular}

\section{Rural development through rice-fish culture in arunachal pradesh}

The productivity of fish depends mainly on the stocked species of fish, duration of culture period, the soil and water qualities and finally on the availability of natural food organisms. Haut and Tan (1980) focused on the ranges of food fish productivity in rice-fish system according to water quality of the system and advocated that rice-fish is an ideal integration in any rice ecosystem having fertile water even with lower depth. The rice-field water in Arunachal Pradesh showed conducive environment (Table 2) for planktonic organisms that practically escalate the production potential of fish species stocked in the field. Saikia and Das (2008) reported that the Common carp (Cyprinus carpio L) stocked in the rice-fields of Apatani Plateau feeds mainly on periphyton colonized on underwater part of the rice-stem. The fish displays opportunistic behaviour rendering its planktivorous nature to periphytophagus nature in these rice-fields. Das et al. (2007) recognized it as self-subtrating periphyton based aquaculture (SSPBA) system for the role played by rice plant as a surface for periphyton growth.

Table 2. Physico chemical properties of rice-field water of Apatani Plateau, Arunachal Pradesh, India

\begin{tabular}{|c|c|}
\hline Properties & Value \\
\hline $\begin{array}{l}\text { Temperature } \\
\mathrm{pH}\end{array}$ & $\begin{array}{l}14-30^{\circ} \mathrm{C} \\
6.00-7.58\end{array}$ \\
\hline Conductivity & $45-70 \mu \mathrm{mhos}_{\mathrm{cm}}^{-1}$ \\
\hline Dissolved Oxygen & $5.8-9.6 \mathrm{mg} \mathrm{l}^{-1}$ \\
\hline $\mathrm{CO}_{2}$ & $8.8-15.0 \mathrm{mg} \mathrm{l}^{-1}$ \\
\hline Net Primary Productivity & $450 \mathrm{mgC}\left(\mathrm{cm}^{2}\right)^{-1} \mathrm{hr}^{-1}$ \\
\hline Gross Primary Productivity & $563 \mathrm{mgC}\left(\mathrm{cm}^{2}\right)^{-1} \mathrm{hr}^{-1}$ \\
\hline
\end{tabular}

\section{Constraints and priority strategies}

The purpose of rice-field is to produce rice. Therefore, the organic practices are centered with an aim towards maximization of rice production. The Apatani Plateau is one of the fertile areas in Arunachal Pradesh from where rice production was estimated as $4000 \mathrm{~kg} \mathrm{ha}^{-1} \mathrm{y}^{-1}$ (Annon., 2006). Considering the extensive available resources of irrigated rice-fields, there lies assured scope for up-liftment both economically and environmentally through rice-fish integration. The income received by farmers in Apatani plateau is low due to lack of adequate knowledge on the technique (Saikia and Das, 2004). The government as well as other social organizations needs to lay their attention towards such eco-friendly technique. The intensifications of modern farming technique 
have still to touch the areas under the rice-fish system, not only Apatani Plateau but most of the rural sectors of the world. On the other hand, a very little attention has been paid to the ecological and economical aspects of rice-fish system. Therefore, it is high time to create the awareness among the farmers on role of fish as bio-controlling agent, maintenance of soil health, nutrient recycling etc., on priority. Furthermore, training of local farmers to orient for rice-fish culture and economic subsidy through bank loan and other incentive may play important role to change the farmer's motives towards this sustainable agro-farming practice. Side by side, thrust of research on the selection and development of rapid growing fish species, compatible combination of optimally productive rice cultivars, use of bio-fertilizer, improvement of agronomic practices suitable to ricefish combination, judicious water management etc., should be initiated to remove certain inbuilt constraints in the system itself with reference to location specificity of rice environment of the state.

\section{Rice-fish culture: Role in poverty alleviation}

Living aquatic resources play a fundamental role in sustaining the livelihood of rural poor in Asia. In many Asian countries, over one half of animal protein comes from fish. Rice-fish culture under either capture systems or culture systems is a low-cost sustainable practice to obtain high value protein food and minerals. At the farm level rice-fish integration reduces use of fertilizer, pesticides and herbicides in the field. Such reduction of costs lowers farmer's economic load and increases their additional income from fish sale. With such savings and additional income, the net productivity from rice-fish farming are reported to be higher than rice monoculture. Halwart (1998) reported that from the practice of fish culture in rice-field with a total gain from savings of pesticides and earning from fish sales, the net income that a farmer obtains upto $65 \%$ higher than rice monoculture. On the contrary, the rice-fish culture increases the yield of rice (upto 25-30\%) besides providing extra income to farmers. According to Brian Davy, the director of International Developmental Research Center of Canada, rice-fish integration is an important area for farmers who are marginalized, cultivate under difficult conditions and find the cost of pesticides and fertilizer financially burdensome (Newton, 2002). Farmers' always require minimal capital input and welcome a low cost farming practice. If proper location specific refinement of packages of practices is done using locally available resources, traditional rice fish culture similar to Apatani Plateau can be turned into low input self-supporting system. The standardized package of practices can be extended as smallscale industry by adopting extension and training program for rural people. China, where rice fish production have moved from very low levels in the early 1980s, has reached over 1.2 million ha in recent years only through integrating fish polyculture with poultry, livestock as the integrated use of manure, grass and other crop as natural feed and fertilizer.

What Peter Edwards (2002) writes is "As aquaculture techniques for poor people are largely in place, greater emphasis should be given to more effective extension of low cost technologies and appropriate management practices for poor people and securing their right of access to and control of resources, rather than technical research". Since aquaculture requires resources such as pond, land, water and other inputs, poor farmers cannot afford the requirements. As a target to understand and meet their needs and to access the common water resources available in their rice-fields, rice-fish culture is the most appropriate technology in recent times.

\section{LITERATURE CITED}

Anonymous. 2006. Annual report. Department of Fishery, Ziro, Lower Subansiri District, Arunachal Pradesh.

Das, D. N. 2002. Fish farming in rice environments of north-east India. Aquacult Asia 2, 43-47.

Das, D. N., Saikia, S. K. and Das, A. K. 2007. Periphyton in rice-fish culture system: A case study from Arunachal Pradesh, India. Renew Agric Food Sys 22(4), 316-319.

Edwards, 2002. Aquaculture for poverty alleviation and food security. Aquacult Asia 7(2), 53-56.

Halwart, M. 1998. Trends in rice-fish farming. FAO Aquacult Newsletter 18, 3-11. 
Heckmann, C. W. 1979. "Ricefield Ecology in Northeastern Thailand". Dr W. Junk Publishers, The Hague.

Huat, K. and Tan, E. S. P. 1980. Review of rice-fish culture in Southeast Asia. In "Proceedings of the ICLARM-SSEARCA Conference on Integrated Agriculture-Aquaculture Farming Systems", Manila, Philippines, 6-9 August (R. S. V. Pullin and Z. H. Shehadeh, Eds.), pp. 1-16.

Newton, P. 2002. Fishing in the Rice Paddy, IDRC Resource Book. Reports 21(2).

Saikia, S. K. and Das, D. N. 2004. 'Aji gnui assonii' - a practice of organic hill farming among the Apatani tribe of Eastern Himalaya. Int J Sustainable Dev World Ecol 11, 211-217.

Saikia, S. K. and Das, D. N. 2008. Feeding ecology of common carp (Cyprinuc carpio L.) in a ricefish culture system of the Apatani Plateau (Arunachal Pradesh, India). Aqu Ecol DOI 10.1007/s10452-008-9174-y. 